\title{
THE CORRELATION BETWEEN SOCIAL DEIXIS AND SOCIAL CLASS IN A SPEECH BY NOBEL PRIZE WINNERS: A SOCIOPRAGMATIC STUDY
}

\author{
Annur Karima Zulyanputri \\ annur19001@mail.unpad.ac.id
}

Lia Maulia Indrayani

lia.maulia@unpad.ac.id

Ypsi Soeria Soemantri

ypsisoerias@gmail.com

Padjadjaran University of Sumed ang, Indonesia

Article History:
Received: $8^{\text {th }}$ May 2020
Accepted: $26^{\text {th }}$ June 2020
Corresponding Author:

Tel.:

lia.maulia@unpad.ac.id

Keywords:

Social Deixis; Social Class

Speech; Absolute;

Relational; Dimensions
This article aims to identify the relationship between one of the linguistic forms such as deixis, specifically social deixis, and the speakers' social class. Thus, the usage of social deixis by Nobel Prize winners in their speech, are analysed. The data are taken from the banquet speech of Nobel Prize winners. This research was conducted to find out the types of social deixis used by Nobel Prize winners using Levinson's theory, which are absolute and relational, and its correlation with speakers' social class. This research applies Block's theory to provide the aspects or dimensions in social class. Furthermore, other additional theories are also provided to support the main theories. This qualitative descriptive research socio-linguistically provides insight into people's social class that is identified through linguistic feature like social deixis. The findings show that both types of social deixis which are absolute and relational can be identified from every speech uttered by the Nobel Prize winners. Through the findings of the research, only the relational type of social deixis can determine the speakers' social class dimensions. They are wealth, occupation, education, and social networking. 


\section{INTRODUCTION}

Communication is an essential part of everyday life. It is a process of carrying and giving message or information from the speaker to the hearer and vice versa to make each other understand the message or information. What is interested in communication is, people do not always or even usually say what they mean (Thomas, 2014). They frequently mean much more than their words actually say. Hence, we can investigate such phenomenon from pragmatics point of view. Levinson (1983) defines that pragmatics is the study of language use. It is the study of the relation between language and context which is basic to an account of language understanding which involves the making of inferences which will connect what has been said before. Pragmatics also could solve the matter between the speaker and therefore the hearer, especially the matter about point of view.

In everyday language, there is one pragmatics aspect called deixis that is commonly used to communicate. The use of terms such as I, you, she, he, it, here, there, now, etc are commonly used in the daily conversation. A deictic expression or deixis may be a word or phrase that points to the time, place, or situation during which a speaker is speaking. Deixis, based on Levinson (2004) is classified into five; person deixis, time deixis, place deixis, discourse deixis, and social deixis. Person deixis concerns with the grammatical person involved in an utterance (e.g., $I$ and you), it refers to the participant role of a referent such as the speaker, the addressee, and referents which are neither speaker nor addressee. Time deixis concerns with the various times involved in and referred to in an utterance (e.g., now, today, and yesterday), it refers to the current time in when the utterance is spoken. Place deixis concerns with the spatial locations relevant to an utterance (e.g., here and there), it refers to a location relative to the location of participant in the speech event, generally the speaker. Discourse deixis that refers to the use of expressions within an utterance to refer to parts of the discourse that contains the utterance including the utterance itself. Social deixis, as this research focused on, concerns with the encoding of social distinction that is relative to participant-roles, particularly aspects of the social relationship holding between speaker addressee or speaker and some referent. 
Furthermore, Levinson (1983: 90-91) in Adane (2014) divided two basic kinds of social deictic information which could occur in language. The first conveys relational information; this may be between speaker and referent (e.g., referent honorifics), speaker and addressee (e.g., addressee honorifics), speaker and bystander (e.g., bystander or audience honorifics), and speaker and setting (e.g., formality levels). The second type of social deixis is absolute which are absolutely reserved for certain speakers and authorized recipients. The prototypical case involves speech by, or to, a royal person.

In connection with the kinds of social deixis, Levinson (1983) also argued that social deixis is related to the aspect of sentences reflecting or establishing the social situation when the speech event occurs which means social deixis is also a deictic expression to distinguish speakers' social class (Purwati, 2015). Furthermore, according to Levinson (1983:63) social deixis is "those aspects of language structure that are anchored to the social identities of participants in the speech event, or relations between them, or relations between them and other referents".

In applied linguistics and sociolinguistics, the relationship between language and social class has been a major concern as sociolinguistics focuses on the study of the relationship between language and society. Snell (2014) mentioned that Labov (1966), an American linguist who conducted a large-scale survey of the pronunciation patterns of residents of the Lower East Side of New York City established that language use correlates with social factors such as social class, ethnicity, and gender. The sociolinguistics surveys conducted by Labov have supported the idea that those social categories controlled one's linguistic behaviour (i.e. language use reflects existing social structure). However, Block (2015) added that social class is unlike dimensions of identity like gender, race, ethnicity, nationality, sexuality, and religion, but social class is about a wide range of experiences in the day-to-day lives of people. Block also defined eleven key dimensions of class, that lists on the table below. 
Table 1. Key dimensions of class (based on Block, 2012, 2014, 2015)

Dimension

Property

Wealth

Occupation

Social networking people, working-class people with working-class people, etc.

Shopping at a supermarket that is "cost-cutting" or one Consumption patterns that sells "healthy", organic products. Buying particular goods and brands.

Material possessions, such as land, housing, electronic devices, clothing books, art, etc.

Disposable income and patrimony (e.g., what owned property is worth in financial terms).

The type of neighbourhood one lives in (poor, workingclass, middle class, gated community, an area in the process of gentrification) or the type of dwelling (individual house, flat, caravan).

The level of schooling attained and the acquired cultural capital one has at any point in time.

Middle-class people tend to socialize with middle-class

\begin{tabular}{cl}
\hline Symbolic behaviour & $\begin{array}{l}\text { Including body movement, clothes worn, how one } \\
\text { speaks, how one eats, pastimes engaged in, etc. }\end{array}$ \\
\hline Spatial relations & $\begin{array}{l}\text { The condition in which one lives: dwelling size, } \\
\text { bedroom size, proximity to others across day-to-day } \\
\text { activities, etc. }\end{array}$ \\
\hline
\end{tabular}

Mobility

The means, disposition, time, and knowledge necessary for travel.

Life chances

Quality of life in terms of personal comfort, access to preventive medicine, life expectancy, etc.

There are numerous researches in language use, particularly in deixis. A research on social deixis has been done by many researchers, one of them is Social Deixis in Twelfth Night that was conducted by Sabir \& Muhammad (2019). Their research was aimed to find out the types of social deixis that mainly occur 
in Twelfth Night by Shakespeare. The findings reveal that there were two types of social deixis; relational and absolute, with relational deictic words as the type of social deixis that mostly occur in the play. Another research on social deixis was conducted by Khidhir \& Majeed (2019), entitled Analysis of Social Deixis in A Night in Khanzad's Life. Apart from the research that conducted by Sabir \& Muhammad (2019), this research was not only concerned with both types of social deixis, but also how each type is related to social identity, relative power, and social relation between the characters in the play A Night in Khanzad's Life that written by Hama Kareem Hawrami. Hence, similar with the previous researches, this research will identify the deictic expressions in banquet speech of Nobel Prize winners. To develop the differentiation that will give new findings and lead to different results, the author tries to identify and analyze the correlation between the use of social deixis and speakers' dimensions of class.

Thus, this research is conducted to identify the types of social deixis used by Nobel Prize winners using Levinson's theory, which are absolute and relational, and its correlation with speakers' social class that applies Block's theory to provide the aspects or dimension in their social class. Levinson (1983) stated that absolute social deixis is a deictic reference usually expressed in certain forms of address, which will include no comparison of the ranking of the speaker and addressee. Meanwhile, relational social deixis is a deictic reference to some social characteristic of referent apart from any relative ranking. To correlate with social class, this research utilizes the theory from Block (2015). In defining the social class, there are at least eleven dimensions of social class which are property, wealth, occupation, place of residence, education, social networking, consumption patterns, symbolic behaviour, spatial patterns, symbolic behaviour, spatial relations, mobility, and life chances (Block, 2015).

Considering this research has been supported with proper theories, a suitable research object is required. Nobel Prize winners' banquet speech is selected as the research object because the feature of social deixis is often applied in the delivery of the Noble Prize banquet speech. It is easier to identify the social deixis in an award-winning speech as it is predicted that the speaker makes references towards someone in their speech such as giving gratitude to someone. 
Based on that fact, the banquet speeches of Nobel Prize winners are arranged as the research object to help this research find the correlation between social deixis and social class.

\section{METHOD}

This research applied a descriptive qualitative approach as this research method was done to describe the correlation between the usage of social deixis with the social class of the speakers. According to Moleong (2013), qualitative research is a research which has a result of descriptive data in the form of written or oral form observing people or behaviour. Data were taken from the official website of the Nobel Prize (NobelPrize.org). The banquet speech of Ada E. Yonath as laureate in Chemistry 2009, Robert J. Lefkowitz as laureate in Chemistry 2012, Richard H. Thaler as laureate in Economic Sciences 2017, and John O'Keefe as laureate in Physiology or Medicine 2014 were taken to be identified as the main data for the study.

The analysis of the data went through several steps. Collecting information, which researchers call data is only the beginning of the research process. Once collected, the information has to be organized and thought about ( $\mathrm{O}^{\prime}$ Connor \& Gibson, 2003). The author started with read over the written transcripts of Nobel Prize winners banquet speech, then detected the deictic expressions, specifically social deixis that used in the speech. Continued by classified the social deixis into relational and absolute social deixis according to theory that proposed by Levinson (1983). Thereafter, both relational and absolute social deixis are linked with its correlation with the speaker's social class based on Block's (2012, 2014, 2015) key dimension of class.

\section{FINDINGS AND DISCUSSIONS}

After classifying the data, 5 utterances are identified in which relational social deixis is applied. From the social deixis consisted of 5 utterances, 4 social dimensions of the speakers' social class can be identified. In delivering the findings of this research, first, the author describes the context occurred in the data. Second, the relational social deixis is highlighted followed by the explanation of why it is considered as the relational type. Lastly, the correlation between the relational social deixis and the identified social class dimension is 
explained. After providing the explanation of relational social deixis, the author provides the list of identified absolute social deixis and the comparison between the absolute and relational type in regards with the correlation of social class.

Relational Social Deixis

Relational Social Deixis to Identify Speaker's Wealth

Data 1: "I want to thank warmly my dedicated chauffeur, Nisse. Without him, I would have been lost in Stockholm, the wonderful, albeit dark city, and consequently miss most of the fascinating events of this magic week."

Speaker: Ada E. Yonath

Social deixis type: Relational

Social class dimension: Wealth

From the data above, Ada E. Yonath spoke in behalf of laureate in Chemistry 2019. She delivered her banquet speech after receiving the Nobel Prize winner in Chemistry in 2009. The social deixis was identified at the end of her speech. It is represented by the phrase of my dedicated chauffeur. By definition, a chauffeur is defined as a person employed to drive a private or rented automobile. The type of social deixis from data 1 is considered as relational social deixis. The deixis used in the data above is a reference to a social relationship between the speaker and other referents in the extra-linguistic context as the chauffeur doesn't present in the Nobel Prize ceremony.

In general, the term of chauffeur has a similar meaning to driver. However, the function of chauffeur and driver in terms of specific duty is completely different. Therefore, the differences produce a level of social class between chauffeur and driver. To be more specific with the term of a driver, it has a lower class than chauffeur which considerably has more high-class term. The reasons of why the term of driver has a lower social class than chauffeur is that firstly, the word driver usually correlates with several job terms such as taxi driver, cab driver, and bus driver. Those kinds of jobs frequently serve people from middle to low social class mostly to provide their daily mobilization. According to indeed.com, the average of a taxi driver's salary in the United States is $\$ 16.71$ per hour and the requirement for a person to be a driver is more general rather than to 
be a chauffeur where almost every person is capable to meet the requirements. Generally, the requirements to be a taxi driver according to THINKLimo is that a person must be at least 21 years old and is capable to drive a car proven by driver's license and insurance. By looking at the requirements, it can be argued that everyone can be a driver.

However, on the other side, a chauffeur is very different compare to a driver. According to THINKLimo, the cost to hire a chauffeur is approximately around $\$ 75$ to $\$ 250$ per hour or all the way to $\$ 1.500$. To be a chauffeur, a person must have more experiences not only in driving matters but also in other matters that can ensure its passengers to enjoy the travel experiences. In other words, a chauffeur is more expert in terms of customer service rather than drivers where they are likely to focus on getting customers from one destination to another as fast as they can and consequently give more prestige and luxury for the customers. From the utterance above, it is clear that the speaker is pleased by the service given by her chauffeur as she described her chauffeur as a dedicated person. Besides, the speaker also elaborates her satisfaction by uttering the expression of "Without him, I would have been lost in Stockholm". Moreover, a company providing limo and luxurious automobile service, stated that chauffeur mostly drives a first-rate vehicle. The example of first-rate vehicle is such as executive vans, limousines, and luxury sedans. The first-rate vehicles which are operated by the chauffeur proves that a chauffeur is a high-class occupation. As the speaker, Ada E. Yonath, uses that social deixis, consequently, resulting in an implicit meaning from the utterance regarding the social class of the speaker.

Regarding with the implicit meaning form the deixis used in data 1 , the deixis has a relation with the speaker's social class. By uttering the phrase of $m y$ chauffeur, the speaker implicitly shows that she has a high social class in terms of wealth. Most a wealthy person, according to Block (2015) is related to financial matters. As it has been mentioned before, by looking at the range of cost to hire a chauffeur, only people from middle to high class can afford the price. In reference with her speech, at the end of the sentence, the speaker utters the expression of "this magic week" and this infers that the speaker has been hiring the chauffeur for a week. Based on the explanation about the price rating of a chauffeur which is 
elaborated before. It is expected that the speaker should pay the chauffeur extra cash as she is served for a full week. Although there is a possibility that the committee of Nobel Prize provides the accommodation for the speaker, the possessive pronoun of " $m y$ " uttered by the speaker reflects that the accommodation of hiring the chauffeur is handled by herself. Based on those circumstances, it can be said that the speaker has no problems in spending that range of cost to hire the chauffeur.

In conclusion, being able to spend the amount of money to hire a full week service from a chauffeur in the city of Stockholm, Sweden where the Nobel Prize is held, it is understandable that the speaker is a wealthy person and hence the speaker has a high class in terms of wealth. Additionally, based on the utterance uttered by Ada E. Yonath, the social class dimension of wealth is implicitly mentioned by her during her banquet speech after receiving a Nobel Prize award.

\section{Relational Social Deixis to Identify Speaker's Education}

Data 2: "Many of our trainees are major leaders in our field of science, a source of enormous pride for both of us."

Speaker: Robert J. Lefkowitz

Social deixis type: Relational

Social class dimension: Education

In data 2, Robert J. Lefkowitz, the winner of Nobel Prize in Chemistry back in 2012, uttered his banquet speech after receiving the award. During his speech, he informed the audience that he and his colleagues always do training mostly about science to the young trainees. The social deixis spotted in the data above can be seen from the phrase of our trainees, it is considered as relational social deixis as it shows a social relationship between Robert J. Lefkowitz with the trainees. The relationship between the two of them is as trainers and trainees. The term of our trainees uttered by the speaker in a speech implicitly shows the speaker's social class in term of his education.

By definition, trainee means a person undergoing training for a particular job or profession. By its definition and the context of the data, it can be implied that the speaker also acts as the trainer for the trainees. It can be shown from the 
use of the word "our" that shows a possession. The definition of a trainer is a person who teaches skills to people and prepares them for a job, activity, or sport.

However, being a trainer is not something that every person can acquire, especially being a trainer in the science field where the knowledge is more complicated compare to other knowledge. To be a trainer in the science field, it can be said that a person must have good credibility and considerable reputation to carry out the process of the training. To be qualified, the trainers must have a high educational background. In relation with the context in data, based on the author's research on the internet, Robert J. Lefkowitz graduated from Columbia University College of Physicians and Surgeons in 1966 with an M.D Degree and later in 1977 he acquired his rank as professor of medicine. Based on those circumstances, a doctoral degree is the highest degree in the educational title and the rank of professor is also one of the highest positions for a person who works in a university. The combination of acquiring his high educational title by completing a Doctoral Degree and acquiring the rank of professor must surely put Robert J. Lefkowitz as an educated person with a lot of experience in certain fields. In results, as Robert is equipped with valuable educational background, many people are willing to become his trainee as they may find him credible to be a trainer. As a consequence, there is a relation between the fact occurred to the speaker and the social deixis uttered in his speech. The social deixis which is represented by the phrase of our trainees shows that the speaker has a high class in terms of education as being a trainer in the science field surely must have a high educational background.

In conclusion, through his utterance of saying our trainees, the speaker implicitly displays social class dimension of education specifically his education to the listeners as it has been mentioned before that the speaker indeed has a high educational background as he managed to acquire professor of medicine title. From that utterance, it can be inferred that the listeners can understand about the social class identity of the speaker and after the explanation above, the utterance in data 2 is reflecting the social class dimension of education.

Relational Social Deixis to Identify Speaker's Occupation 
Data 3: So what did I do to get up here? I discovered the presence of human life in a place not far, far away, where my fellow economists thought it did not exist: the economy.

Speaker: Richard H. Thaler

Social deixis type: Relational

Social class dimension: Occupation

Based on the data above, the context occurs is that Richard H. Thaler is appointed as the winner of the Nobel Memorial Prize in Economic Sciences. After receiving the award, he delivers a speech. In his speech, this research identifies a relational social deixis used by the speaker. As it is shown in data 3, the relational social deixis is identified because of the usage of the phrase "my fellow economists". The phrase is a referent to the extra-linguistic context as they are not present during the presentation of the speech. It shows the relationship between the speaker and the addressee. The word of fellow means a person in the same position, involved in the same activity, or otherwise associated with another. It can be implied that the speaker and the addressee have a similar social class or in other words, they are in the same level. However, the phrase of my fellow economist has an implicit meaning for the audience of his speech and it is related to the speaker's social class.

The social deixis applied in data 3 implicitly shows the speaker's social class in terms of occupation. The definition of the word economist is someone whose work is to study the way in which economies work, or who studies developments within a particular economy. It can be said that the word of economist refers to an occupation. This occupation is attached to the speaker as it is supported by the fact that the speaker uses the word "fellow" and in results, it can be said that the speaker's occupation is also an economist just like his fellows.

An economist is regarded as one of the prosperous occupation or in other words it is a high-level occupation. According to glassdoor.com the average economist salary in the United States is $\$ 109.333$ per year. That amount of salary makes economist as one of the prosperous jobs. Based on the fact, economist job is considered as one of the prosperous jobs. However, it is not only because of the 
aspect of the salary, but an economist is also considered as an essential position in business due to the fact that an economist can determine whether a business can be successful or not. Some of the duties done by the economists are doing some research to analyse economic issues. Afterwards, the result of the analysis is applied as the guidelines to make business policies. According to that process, an economist will surely be valued highly. Consequently, the social deixis uttered in the speech of Richard H. Thaler indicates that the speaker has a high-level occupation. In the data above it shows that the speaker implicitly acknowledges that he has a high social class in terms of occupation.

In short, the utterance in data 3 which uttered by Richard $\mathrm{H}$. Thaler implicitly displays the identity of the speaker himself. The utterance based on the pragmatics point of view has a hidden meaning which can describe the speaker himself. The expression of my fellow economists shows that the speaker has a high level in a social class specifically in occupation dimension according to the classification framework by Block (2015). Furthermore, Condit (2018) in Bucchi, Loner, and Fattorini (2019) stated that banquet speeches offer several insights into the images of science and scientific profession that Nobel scientists implicitly or explicitly convey to the audience.

Relational Social Deixis to Identify Speaker's Social Networking

Data 4: "I want to end by recognising and thanking our many collaborators and colleagues too numerous to mention in this short speech, our universities, UCL and NTNU, and our generous funders. "

Speaker: John O’Keefe

Social deixis type: Relational

Social class dimension: Social Networking

According to data 4, the context occurs is the winner of the Nobel Prize in Physiology or Medicine in 2014 John O'Keefe, delivers his banquet speech. At the end of the speech, he utilizes the feature of social deixis which is represented by the phrases of our many collaborators and colleagues, and, our generous funders. Furthermore, the phrase is a referent to the extra-linguistic context as they are not present during the presentation of the speech. In other words, it shows 
the relationship between the speaker and the addressee. As the context of utterance in data 4 shows a sign of gratitude towards the addressee, it can be implied that the relationship between the speaker and the addressee is on the same social environment. Through the use of the social deixis in the speaker's speech, it can be identified that the speaker reveals his social class dimension which is social networking.

The speaker shows the state of his social networking through the use of social deixis. It is understandable that to complete his research, the speaker explains that there are many people give a lot of contribution both directly and indirectly. It is proven that the speaker elaborates the situation by giving gratitude to three different groups which are collaborators, colleagues and funders. First of all, the definition of the word collaborator is a person who works jointly on an activity or project. By its definition, to carry out his research, John O'Keefe works in team or group not only by himself. The collaborators can be people who work voluntarily for him or people who get paid and execute some administrative work for the research. To gather those number of people especially in gathering volunteers, it requires great social networking for the speaker so that they can agree to work together with him.

Secondly, the definition of a colleague is a person with whom one works in a profession or business. It can be understood that the speaker did the research that is winning the Nobel Prize with the help of many people. The words colleague may have different interpretation with the previous word. The level of people in this area of colleague word may have a more important role and have a higher social class in terms of occupation. By its definition, it is clear that colleague is people in a particular profession or business so it can be inferred that they may be more highly valued than collaborators. Colleagues and collaborators have different social-class term due to the fact colleagues may get paid higher than collaborators.

Thirdly, the definition of the word funder is a person or organization that provides money for a particular purpose. Among the subjects mentioned in the speaker's utterance, this subject may have the highest social-class because, without the presence of funders, the speaker's research may not have been 
conducted. As funders provide money that can cover up the operational of the research, everyone involved in the research including its mastermind, John O'Keefe himself may value them highly. It can be shown from the speaker's utterance where he uses an adjective of generous to praise the funders. However, to find funders that willingly provide funds for research is not a simple job. First of all, the proposal of the research itself must have an excellent concept so that the funders can be impressed. Second, although the research has an impressive set of proposals, the one who submits or carry the proposal plays a more important role. In this case, John O'Keefe himself is the reason that this research can gather funds from various funders. Hence, it can be implied that the speaker's research is supported by someone that can provide a huge amount of fund since the speaker has a good reputation among his social networking.

In regards to its connection with the social class dimension, those phrases mentioned earlier indicate that the speaker has a wide range of social networking. To gather a lot of collaborator and colleagues needs a wide social networking. From the context above, it is believed that the collaborators and his colleagues get many benefits in helping the speaker doing the research. Additionally, it is harder is for the speaker to find funders to support his research. However, the speaker managed to find one and give the funders a huge feedback by winning the prize.

To conclude, the utterance in data 4 shows the relational type deixis and moreover, it also has an implicit meaning of revealing the identity of the speaker himself. The identity of the speaker is revealed by the expression of our many collaborators and colleagues, and our generous funders. That expression shows the speaker's social-class that covers the dimension of social networking. John O'Keefe is the perfect example of Block's theory (2015) of social-class of dimension of social networking as he socializes with people from various socialclass.

\section{Absolute Social Deixis}

This research has identified several absolute social deixis uttered by four Nobel Prize winners. Here is the list of the deixis followed by its definition: 
Table 2. Absolute Social Deixis in the Banquet Speech

\begin{tabular}{|c|c|c|}
\hline Words/Phrases & Type & Glossary \\
\hline Your Majesties & Absolute & $\begin{array}{l}\text { A title of respect used } \\
\text { when addressing a } \\
\text { monarch of higher rank } \\
\text { than a prince; that is, a } \\
\text { king, queen, emperor, or } \\
\text { empress. }\end{array}$ \\
\hline Your Royal Highnesses & Absolute & $\begin{array}{c}\text { Used as a title for a } \\
\text { member of a royal } \\
\text { family. }\end{array}$ \\
\hline Your Excellencies & Absolute & $\begin{array}{l}\text { The title of someone in } \\
\text { an important official } \\
\text { position, the one who } \\
\text { represents certain } \\
\text { government. }\end{array}$ \\
\hline
\end{tabular}

Comparing to the relational social deixis, absolute social deixis indicates that there is no comparison of ranking between the speaker and the addressee. The addressee is absolutely higher above the speaker and mostly the absolute type is a reserved term for someone who has an essential position in a certain country or government. Based on the background of the Nobel Prize event, it corresponds with the terms or words used as the absolute deixis type as the event involve people who have essential position especially the royal family and governments of Sweden and Norway as the host of the event. In comparison, the relational type is more suitable to be used as an indicator for determining the speaker's social class whether the speaker is higher than the addressee or not. This happens as in absolute social deixis, the addressee cannot be compared to the speaker so that the addressee is always higher than the speaker.

\section{CONCLUSIONS AND SUGGESTIONS}

Based on the findings of the research above, it is concluded that both types of social deixis which are absolute and relational can be recognized in Nobel Prize winners' banquet speech. Furthermore, social deixis can be correlated with speakers' social class. However, only the relational social deixis that can describe the speakers' social class even more than the absolute deixis. With this feature, 
the speakers' identity can be easily identified while the absolute type is more describing the social class of the addressee. Through the finding of the research, the relational type of social deixis can determine speakers' social class dimension and they are wealth, occupation, education, and social networking.

\section{REFERENCES}

Adane, D. (2014). Social Deixis in Hadiyya. International Journal of Language and Linguistics, 2(5), 301-304. doi: 10.11648/j.ijll.20140505.12

Block, D. (2012). Class and Second Language Acquisition Research. Language Teaching Research, 16, 188-205.

Block, D. (2014). Social Class in Applied Linguistics. London, UK: Routledge.

Block, D. (2015). Social Class in Applied Linguistics. Annual Review of Applied Linguistics. 35, 1-19. doi: 10.1017/S0267190514000221.

Bucchi, M., Loner, E., Fattorini, E. (2019). Give Science and Peace a Chance: Speeches by Nobel Laureates in the Sciences. doi: https://doi.org/10/1371/journal.pone.0223505

Glassdoor Company Salaries. Retrieved, May 18, 2020. From https://www.glassd oor.com/Salaries/index.htm

Khidhir, D., \& Majeed, S. (2019). The Analysis of Social Deixis in A Night in Khanzad's Life. Journal of University of Raparin, 6(2), 35-56. doi: https://doi.org/10.26750/Vol(6).no(2).paper3

Levinson, S. C. (1983). Pragmatics. Cambridge: Cambridge University Press.

Levinson, S. C. (2004). Deixis and Pragmatic. In: L. Horn \& G. Ward (eds). The Handbook of Pragmatics. Oxford: Blackwell, 97-121.

Moleong, L. J. (2013). Metode Penelitian Kualitatif: Edisi Revisi. Bandung: PT. Remaja Rosdakarya.

O’Connor, H., \& Gibson, N. (2003). A Step-By-Step to Qualitative Data Analysis. Pimatiziwin: A Journal of Aboriginal and Indigenous Community Health, 63-90.

Purwati, T. I. (2015). Social Deixis of Princess Diana in Diana the Secret of a Princess Movie. Language Horizon - Jurnal Mahasiswa Unesa, 3(2).

Sabir, A., \& Muhammad, B. (2019). Social Deixis in Twelfth Night. Zanco Journal of Humanity Sciences, 23(1), 291-303. doi: https://doi.org/10.21271/zjhs.23.1.20

Snell, J. (2014). Social Class and Language. In Jan-Ola Östman and Jef Verschueren (Eds). Handbook of Pragmatics: 2014 Installment. Amsterdam: John Benjamins.

Taxi Driver Salary in United States. Retrieved, May 18, 2020. From https://www.indeed.com/career/taxi-drivers/salaries 
The official website of the Nobel Prize. Retrieved, May 1, 2020. From (https://www.nobelprize.org)

THINKLimo - Limo \& Luxury Coach Service. Retrieved, May 1, 2020. From (https://thinklimo.com)

Thomas, J. A. (2014). Meaning in Interaction: An Introduction to Pragmatics. Lond on and New York: Routledge. 